\title{
Marginal Stories? \\ The Perspectives on Citizenship of Multiple Citizens and Multicultural Persons of Estonia
}

\author{
Leif Kalev and Rein Ruutsoo
}

\begin{abstract}
This article focuses on practices of citizenship in Estonia by persons with multiple citizenship or multicultural background. In the previous stages of research on this topic primary attention was paid to national citizenship, multiple citizenship and European Union citizenship as institutions, as well as the role of citizenship in the construction of European space. Expected "configurations" of multiple citizenship as articulated in Marshallian (1992) terms, as well as linkages between different spaces of membership (national and not-national) of citizenship as perceived by the national decision makers, mapped both avenues and bottlenecks for the future. Our research raises questions and problems related to citizenship as both an essential tool of nation building and of EU integration (cf. Ruutsoo and Kalev 2006, Ruutsoo and Kalev forthcoming).
\end{abstract}




\section{Introduction}

This article focuses on practices of citizenship in Estonia by persons with multiple citizenship or multicultural background. In the previous stages of research on this topic primary attention was paid to national citizenship, multiple citizenship and European Union citizenship as institutions, as well as the role of citizenship in the construction of European space. Expected "configurations" of multiple citizenship as articulated in Marshallian (1992) terms, as well as linkages between different spaces of membership (national and not-national) of citizenship as perceived by the national decision makers, mapped both avenues and bottlenecks for the future. Our research raises questions and problems related to citizenship as both an essential tool of nation building and of EU integration (cf. Ruutsoo and Kalev 2006, Ruutsoo and Kalev forthcoming).

The aim of this article is to study how persons of multiple citizenship or multicultural background - the groups that likely have a more personal viewpoint on the issues of citizenship and are situated in the effective contact zone of Estonian society - reflect the meaning of citizenship in its different forms in Estonia.

Due to the link between (multiple) citizenship as a resource for constructing personal life-projects and the actual status of respondents in Estonian society, research into both subjects is of interest to us. We also examine what reasoning guides political, civil and social participation, as well as what other factors are seen as important for participation and why.

More concretely, this article focuses on (1) the general attitudes toward citizenship; (2) practical experiences with multiple citizenship; and (3) substantial dimensions of citizenship, including perceptions of full membership in society, loyalties and identities. We first discuss the key concepts, context and methodology of research. Thereafter we present the main findings supporting our lines of argumentation. We will conclude with generalisations and recommendations.

Citizenship is a concept usually linked to exclusive membership in a political community, i.e. nation state. The relations between state institutions and citizens (as well as other types of residents, e.g. denizens, cf. Hammar 1990) are manifold: mutual rights and duties linked to status are complemented by societal practices and influence each other constantly. Due to the processes of transnational migration and globalization, the singleness of citizenship has become contested (cf. Bauböck and Rundell 1998, Castles and Miller 1998, Castles and Davidson 2000, Waters 2001). There are many people who either temporarily of permanently live in a country other than their native one in contemporary world. Some of them have developed real affiliations to both their country of origin and country of residence. Some states have responded by legalizing dual or multiple citizenship in such cases.

Contemporary citizenship is notably diverse. In addition to the distinction of status and practice it is possible to differentiate between vertical and horizontal citizenship. Vertical citizenship refers to various levels of membership, from a local community to regional, national, supranational, or even world citizenship (cf. Heater 1999). Multiple citizenship is usually understood as holding several national citizenships. Horizontal citizenship encompasses both public and private spheres and is linked to different 
areas of life, including civil, political, socio-cultural and socio-economic fields. Additionally, horizontal citizenship may also be understood as a life-long learning process.

It is useful to distinguish between citizenship as an analytical tool and citizenship as a legally based phenomenon. Analytically, citizenship characterizes a person's emancipation and membership in a given society, and Andersen and Hoff (2001: 3) define citizenship as having three analytical dimensions: rights (and duties), participation and identities. Citizenship may also be understood as a cumulative or continual learning process. It may also be understood as an analytical tool that one can use to analyse citizenship as a legal status, as well as all the other statuses and memberships of persons.

Our subsequent discussion is based on citizenship as perceived by interviewees, i.e. primarily as based on the legal status. Legally, citizenship is a clearly defined set of rights and duties setting the possibilities for citizenship as practice (in political, sociocultural and economic terms). A citizen is expected to act within an enacted space of rights and duties, to be loyal, and to take a passport when going abroad to show into which country he/she belongs and which country takes care of his/her needs, etc.

\subsection{Citizenship: a resource and a set of strategies of accommodation}

The years 1987-91 marked the period of Estonia regaining its independence. Independence mobilised historical and socio-cultural arguments, and also defined strategies in discursive construction of approaches to Estonian citizenship and dual citizenship. Recent discourse studies on nation building have revealed related security and state-building discursive formations, which obviously also have significant impact on citizenship discourse formation.

All people are in touch with both "practical" and "symbolic" worlds in terms of citizenship: along with practical choice and legal options citizenship is the matter of belonging to "imagined communities" of identity and loyalty. Both of these main dimensions of self-description were included in the structured questionnaire we employed for this study. We found out that the two play important roles as essential markers of self-image in different generations of immigrant residents of Estonia, who have had to decide where they belong since the collapse of the former Soviet Union.

To better understanding what constitutes the main object of our research, it should be remembered that Estonia has not become a country of immigration since its independence was restored. Since independence, Estonia has accepted only ca. 7000 new legal permanent residents (Postimees 10.10. 2005), mainly from neighbouring countries (Latvia, Lithuania) that do not allow dual citizenship. Other new legal permanent residents come from Germany, Sweden and Finland, which in recent years have become more positive about allowing dual citizenship. Much of the movement has been related to family life but is also related to temporary studies in universities and employment. Alongside these legal immigrants/residents, Estonia has only small group of refugees.

However, a residue of the Soviet regime remained after independence: Estonia needed to integrate a ca. 500,000-strong Soviet-time immigrant community that had not yet 
obtained noticeable qualities for adjusting to the local socio-cultural environment. Attitudes of the bulk of immigrants were defined by the political task set by Moscow, namely the consolidation of the Soviet Empire, the annihilation of local identity and the acculturation of captured nation. As a result, Soviet Estonia was effectively a segmented society, with the native (ethnic Estonian) community enjoying some cultural rights, and the arriving immigrant population being developed towards a Russophone "Soviet people" segment (cf. also Kalev and Ruutsoo forthcoming).

The restorationist citizenship policy that has been dominant in post-independence Estonia maintained much of the segmentation of society, paving the way for the emergence of two communities with different statuses. That segmentation also became instrumental in producing rigid identity boundaries between the mainstream Estonian societ and the bulk of mainly Russophone, Soviet-time immigrant residents.

The discourse of "Russopohones" popular among scholars is misguiding because it neglects to mention that, despite the spread of "monolinguality", Estonia bears traces of a multicultural community. Russian speakers were in no way a homogenous "civil garrison" as politicians who supported exclusionist position preferred to treat it. Yet at the same time the community of Soviet immigrants was to a significant extent developed into the "Soviet people". The term, created in the 1970s, refers to the ideologised concept, which labelled de-nationalised minorities with multicultural background, whose ethno-cultural identity/belonging and linguistic affiliation was suppressed. At the same time, the term referred to discourse that equalised Soviet citizens with the "Soviet patriot".

Main trajectories related to obtaining of Estonian citizenship and retaining of the other citizenships have their background in an obvious logic of solving problems that are typical to a post-colonial and post-Soviet country needing to come to terms both with political consolidation and maintaining its independence. Both qualifiers - post-Soviet and post-colonial - are very important in respect to Estonian attempts to understanding the challenges faced by its residents, be they citizens or non-citizens. Citizenship issues in practical terms are not problems of an abstract dispute on democratisation and do not target the European context first of all (the coming five years likely will not bring a fundamental change) but a pattern from past. Proud patriots of "Grossmacht" (in Estonia's case, the Soviet Union) are stilll very much in a state close to shock. They have lost their traditional landmarks, and the acquisition of new loyalties and identities related to a "resurgent state" is a point of great personal challenge (Pettai and Proos 1999, 21-25). The Soviet system (based on state-socialist ideology) and the "Grossmacht" approach (the building of Russian Empire) patterned quite rigid identities. In this perspective, the status of "dual citizenship" acquires a very specific meaning.

\subsection{Specifics of research context in contemporary Estonia}

With regard to multiple citizenship and multiculturalism there are two key aspects placing Estonian research into a different context than that performed by other countries participating in the DCE project: 
1. Multiple citizenship is prohibited by law in Estonia. This makes it hard to find (illegal) multiple citizen respondents and, in case of all others, to ask something more than general questions on multiple citizenship.

The illegality of dual citizenship originates from the Citizenship Act, which prescribes that an Estonian citizen shall not simultaneously hold the citizenship of another state $(\S 1)$. However, as the Constitution states that no one shall be deprived of Estonian citizenship acquired by birth $(\S 8)$, there is no effective sanction regarded as constitutional for native citizens holding dual or multiple citizenship. In practice, this is also the case for naturalized citizens, as there are no investigative procedures and the possible sanction of depriving Estonian citizenship is not in use.

Thus, access to multiple citizenship can hardly be seen as up to personal choice. The individuals with multiple citizenship usually belong to the privileged group who, having obtained Estonian citizenship by birth, cannot in principle be deprived of the Estonian citizenship. The naturalised Soviet-time immigrants and their descendants with multiple citizenship prefer to keep an especially low profile.

In the last population census in 2000, 209 persons declared themselves as dual or multiple citizens (data of the Statistical Office of Estonia). This may be due to the anonymity factor of censuses, and some of the respondents might have been temporary visitors to Estonia (holding dual citizenships, both other than Estonian). However, the groups of Estonian-Russian (78 persons) and Estonian-Finnish (72 persons) citizens indicate that dual citizenship is actually present in Estonia.

However, our experience in interviewing indicates a somewhat different range and composition of multiple citizenry in Estonia than is reported by census. Many of the dual citizens we reached hesitated or declined to speak about their experiences, and it is most likely they were not covered by the population census data.

In sum, one can highlight at least three obstacles for data collection on multiple citizenship:

- First, in Estonia there is very little knowledge about a stock of people who hold multiple citizenship (statistics is fully incomplete).

- Second, due to the specific context (illegality of multiple citizenship), it is hard to agree on a more thorough interview. In addition to this, it is almost impossible to reach agreement on interviews with people who hold multiple citizenship illegally.

- Third, the respondents with multiple citizenship usually don't display their specific status in everyday life and because of inevitable links to kin, it is hard for some Estonians to reveal their citizenship status. For this reason respondents have limited experience in how the status of a dual citizen could possibly affect their everyday practices, their treatment by officials and employers, etc. 
2. The personal background of the interviewees is in many ways very different from that of other DCE project countries due to historical reasons. This gives us a specific interviewee pool.

The Estonian groups that could be seen as target groups for the survey are composed of people having trajectories of life histories that were historically inter-related but without shared characteristics. Both resulted from Soviet annexation that created (1) a large Estonian Diaspora (ca. 100,000), of which a part has now returned, and (2) the group of Soviet-time immigrants and their descendants living in Estonia.

After 15 years of independence, the practical situation of both these groups is quite different from the target groups of other DCE countries. At the same time, other similar groups are missing because, since regaining independence, Estonia has been predominantly a country of emigration with very few new immigrants.

The returned exiles that constitute a substantial part of multiple citizens in Estonia are of ethnic Estonian origin, and those of them who have stayed in Estonia $^{1}$ have already integrated into society relatively well. ${ }^{2}$

The persons with multicultural backgrounds belong to the Soviet-time, mixedorigin, Russian-speaking segment of the population that numbers ca. 400,000 people. It is relatively hard to decide which individuals to select for the 40 interviews. In any case, the interviews cannot be very representative of the whole segment of multicultural population.

A significant part of the multicultural residents (i.e. at least one quarter) descend from the historical Russian minority of Estonia. Also, the Soviet-time immigrants have lived here at least 15 years, as immigration virtually stopped after Estonia became independent. Despite such a long period of residence, the levels of integration within the group vary greatly. In fact, we can still speak of a sizeable mono-cultural minority that effectively minimizes its everyday societal contacts and lives indoors watching Russian TV.

The above-described situation implied a particular strategy for planning interviews. We had to adapt the common frame questions to a situation of illegal dual citizenship. There was little sense to ask very detailed questions on dual citizenship (e.g. views on dual citizenship in education).

In addition to this, our research was influenced by the results of the survey among decision makers conducted in 2004 in Estonia (cf. Ruutsoo and Kalev forthcoming). The attitudes expressed in the survey were also good starting points for the interviews with multicultural persons and those holding multiple citizenship:

\footnotetext{
${ }^{1}$ Some of the returned exiles left Estonia again due to various reasons, including quality of life, employment, family issues, etc.

${ }^{2}$ We succeeded in finding some multiple citizens with some other (former Soviet Union) background as well, but not in considerable numbers (Of course, a possible reason may also have been their preference to stay under cover.), and even these were usually reluctant to participate in the interviews.
} 
1. The decision makers were generally in positions suitable for nation state building, i.e. the answers to questions about the general attitudes expressed patriotism, concerns about national culture, doubts about alternative modes of citizenship, etc. At the same time, the decision makers respected other cultures.

2. While a kind of nationalism prevailed in general attitudes, the positions were at the same time clearly influenced by legislative settings in force in the state, as indicated also by the data of other countries.

3. Concerning everyday practical arrangements, the attitudes were much more instrumental and more compatible to a human rights discourse. The rights of multiple citizens were acknowledged in at least one country, in many cases both countries. Attitudes on duties varied more, but some things, such as conscription, were also required in both countries.

4. As a result of such factors, national citizenship was predominantly understood in terms of patriotism and loyalty, as an exclusive relation between state and citizen. Multiple citizenship was clearly rejected by respondents if they were directly asked, although respondents showed more pragmatism in everyday arrangements. European Union citizenship was welcomed in its current form, but substantial deepening of the concept clearly wasn't welcomed.

5. At the same time, respondents showed a significant lack of knowledge concerning the issues related to citizenship as reflected especially by openended questions. For example, some decision makers even didn't know the EU citizenship existed.

We were interested whether such patterns are also somehow reflected in the fact that the two groups of interviewees came from significantly different situations and positions in society, as some interviewees would likely have a more personal viewpoint both on the issues of citizenship and on being situated in the effective contact zone of the Estonian society.

\section{Methodology of the study}

\subsection{Research design}

We addressed individuals including: (1) people who were citizens of two or more countries, and (2) people who had a multi-cultural (multi-national) background but only one (or no) citizenship. As discussed above, these groups had some special characteristics compared to the other DCE countries.

Due to the specifics of the Estonian context we decided partly to diverge from the main research design and to concentrate on issues that are discussable in the Estonian context. We developed a framing questionnaire with 12 thematic questions generally structuring the interview, and we added some questions on life direction if it seemed appropriate. The framing questionnaire focused to the following topics: 
1. General attitudes on national, multiple and EU citizenships. This included interviewees' understandings of the concepts and their relations, their positions on multiple and European citizenship, and their positions concerning the complicacy of naturalisation and the prohibition of multiple citizenship in Estonia.

2. Practical experiences with multiple citizenship. We asked what effects the interviewees expected while deciding to obtain multiple citizenship and how were/are these expectations met in practice.

3. Substantial dimensions of citizenship. In this context we discussed interviewees' personal viewpoints on identity and loyalty. The second subblock focused on belonging, i.e. being a full member of society covering both the interest to participate and reflections on actual personal status in society (using Marshallian dimensions and focusing on local, national, EU and world levels).

Within each of these blocks, we asked some more detailed questions during the interviews, depending on the answers to the framing questions.

Semi-structured interviews that evaluate identity feelings, attachments to different institutions, explain visions of respondents on acquiring of citizenship etc. build up narratives, which have behind them sets of discourses. These discourses have a formative role in respect of perception of citizenship as an institution.

The interviews were analysed qualitatively. The interviews of single citizens are used to analyse, compare and reflect the different meanings of citizenship and practices of membership. As already mentioned, the linkage between (multiple) citizenship as a resource for constructing personal life-projects and the actual status of respondents in Estonian society mark the core interest of our research.

We will first discuss the responses on the basis of the blocks of the questions and then try to bring out the main positions concerning citizenship, multiple and European citizenship, as well as perceptions on integration of the society.

The answers will not provide us with representative information on overarching attitudes among multiple citizens and multicultural persons, but nevertheless the answers provide us with knowledge about the existing perceptions and lines of argumentation.

\subsection{Data collection and description}

The research data was gathered through semi-structured interviews carried through email and in person. The interviewing style was semi-formal when seeking answers to the common questions of the project. Nevertheless, the respondents were also allowed to express themselves freely while maintaining the general direction and shape of the interviews. 
Altogether 78 interviews were conducted; 37 with persons who held multiple citizenship and 41 with individuals of a multicultural background. Both "internal" (loyalty, identity) and "external" spaces (formal or attributed rights) of citizenship were studied in respect of both groups.

The interviews were mostly carried out on a co-presence basis in the Tallinn University facilities and in coffee shops, but also in the homes or workplaces of many respondents. First of all, persons holding dual citizenship were visited at their homes. A snowball approach became the most effective means of finding dual citizens from the émigré circles, who have built a small sub-community in Estonia.

There were about ten interviews received by e-mail as a result of special agreements with people with strict timetables or less opportunities to move. Based on the experiences of interviewing we expect to have reached a more active and open group of interviewees than the target group average.

Most of the interviewees inhabit Tallinn nowadays, but their background and experience range from Saaremaa Island of the southwest to the Ida-Virumaa region in the northeast if speaking about Estonia, and from the vast territories of FSU in the east to the US in the West and Africa in the South otherwise. All the interviews were conducted in Tallinn (there were ca. five interviewees just visiting Tallinn because of other issues and currently living elsewhere).

Some respondents mentioned difficulties in understanding certain framing questions. In such cases the interviewers reformulated the questions. Explanations of the terms (such as multiple citizenship, social citizenship, etc.) were provided if asked for; in the beginning the respondents were free to define the terms themselves (and thus make their own questions in a way). There was some difficulty in answering the more abstract questions.

The interviews were conducted in Estonian or Russian and, in some cases, to some extent also in English, but they were transcribed directly into Estonian with very few exceptions (e.g. the e-mail responses). The interviews lasted between 45 and 90 minutes, with the longer interviews involving three additional questions for multiple citizens.

We had to put much effort into finding the multiple citizens, into reaching an agreement on interviewing, and into conducting interviews in ways the respondents regarded as acceptable. According to our findings, the respondents with factual dual citizenship (Estonians practising dual citizenship) have their background in the following groups of people:

- Estonian refugees or émigrés (usually referred to as exiles in this article) and their descendants, who obtained citizenship of the host country and actualised their Estonian citizenship usually after Estonia restored its independence (23).

- They are children from the parents with different citizenships (Estonian and other) (5).

- They are children from the foreign parents who hold multiple citizenship (1). 
People with multiple citizenship are sometimes embarrassed because of their status and are reluctant and often decline to give the interview. Even if we decided to interview whomever agrees and used various techniques to reach multiple citizens (sometimes more reminiscent of the work of a detective than that of a researcher) to persuade them to agree to the interviews, many declined, especially among the group with roots in the FSU countries.

On the other hand, there was no problem in finding people belonging to the group of those with multicultural backgrounds - here the question was more one of whom to select. We decided to focus on the patterns of actual integration as reflected by the more successful groups, i.e. younger generations. This should show the various logics behind integration. However, the logics of marginalisation are also present, especially as reflected in the comments on parents or relatives, but also in case of some interviewees. Represented segments of Russophones are made up of these people with a multicultural background who have created a strategy for integration. This approach explains the relative weakness of the "desperate" attitudes or destructive ideologies among interviewees.

A group of respondents with only one - Estonian or Russian - or no citizenship (in truth or possibly in some cases due to reasons of personal security) but with multicultural (multiple citizenship) backgrounds have obtained Estonian citizenship by naturalisation, or via their parents' naturalisation. We did not meet any Estonian by birth that had given up or failed to restore his/her citizenship. Naturalised Estonian citizens obtain absolutely the same rights as the native ones. But in terms of practising multiple citizenship, they found themselves in a disadvantaged position because of loopholes in legislation. Despite the fact that they usually have a good motivation for carrying multiple citizenship (multinational background, language competence up to bilingualism, shared cultural identities, etc.), their legal status as naturalised citizens makes sanctions, which prohibit multiple citizenship, effective.

Respondents with one citizenship but with multicultural backgrounds belonged mainly to the younger generations of Soviet-time immigrants. The interviews aimed to touch to the discursive space that shapes ways of thinking and the acting strategies of people, who can be described as operating in the "border zone" or "contact area" in terms of multicultural background or multiple identity. Their ways of perceiving Estonian citizenship and of constructing their identities and loyalties to communities, etc., in many cases came out in the structured interviews.

It was difficult to follow very distinct data collecting and research strategies in collecting some kind of representative sample. Additionally, the comparison of these groups was complicated because our respondents did not build any constructed sample. The methods used to find respondents varied: The westward sample, which very much overlaps with sample of persons who have dual citizenship, was composed very much as based on snowball techniques. The sample of eastward respondents, which is very much the same as people with a multicultural background, was selected more deliberately.

Selecting the "control group" from respondents with multicultural background but with one or no citizenship would have been simplified if we had comparable objects and groups with more or less similar patterns. Research was problematized because of 
very large scope of issues, which made it hard to put research questions and hypotheses about expected regularities.

But, in general, the structured interview looks to be a rather proper method for dealing effectively with such complex issues as the construction of discourses of/on citizenship and multiple citizenship. Our study revealed that, along with appealing to practical purposes, popular discourses as socio-cultural resources and as patterns of identity formation play an essential role in self-construction of people in terms of citizenship. Our research made it possible to follow to what extent subjective perceptions and experiences pattern practical discourse on citizenship, and also how they are used in the legitimisation of discourses. A "generation marker" seems to be an important discriminator in the formation of different discourses.

\section{Perspectives on citizenship: political nation vs. civil citizens}

\subsection{General attitudes}

Both subgroups of interviewees showed broadly similar patterns with regard to general positions concerning national, multiple and European citizenship. Most of the interviewees were influenced by the logic of nation state building. The answers to general questions contained many references to patriotism. Quite logically, national citizenship was first of all interpreted in terms of patriotism and loyalty, reflected in the following samples:

"I am a citizen of a state, loyal to it and supporting it" (Toivo).

"Being a citizen is good if it makes you feel proud and good" (Jüri).

However, a sub-stream of instrumentalist attitudes was also clearly present in case of national citizenship, as the following sample demonstrates:

"With my two passports I can travel through all Eurasia" (Tiina)

With regard to access to Estonian citizenship by naturalisation there existed a difference between perceptions and practical experiences. While the persons having actually passed naturalisation examinations characterised the questions as reasonable and possible to meet, the people without such experience suspected the examination requirements to be too hard. However, the answers to the question on whether the existing naturalisation conditions were justified were generally positive in both cases.

The experiences and attitudes on civic education are also relatively homogenous. The only exception was between the youngest generation that has had to learn by themselves and the youngest ones that have already had civics classes at normal school. Almost all the respondents stressed the importance of civics in case of educating new generations, while a few also stressed the importance of personal interest and activeness.

As already explained, it was possible to discuss multiple citizenship only in general terms. Discussions on multiple citizenship were as a rule conducted with a discursive 
connection to patriotism. Mostly, it was not regarded as a very positive solution. Even multiple citizens themselves were often not too happy with their situation:

"Multiple citizenship is very dangerous. It can cause many problems" (Sander)

"I can see no conflict. It is technical - I obey the laws. In Estonia I am citizen of Estonia" (Karl).

Some multiple citizens referred to real connections or affiliations with two states as a kind of justification (However, at the same time such a situation showed they felt necessity of justification in this issue.):

"In both countries where I live and that are important to me, I have the destiny to participate" (Juhan).

There existed also some elements of cosmopolitanism. However, the main discourse we found was nation state oriented in terms of general attitudes and quite instrumental in most everyday practical issues. This was also the same case in responses from multiple citizens and multicultural persons:

"Dual citizenship is the possibility to travel freely from one state to another. The possibility to live in both states according to one's will and to live in many states" (Evi).

"I feel loyalty towards all the states of the world" (Maria).

Attitudes on EU citizenship were also in accordance with such a pattern. EU citizenship was warmly welcomed in its current thin form as a bonus package of rights complementing national citizenship:

"In the form EU citizenship exists nowadays it is very good and beneficial for all. ... However I wouldn't like EU citizenship to be the main citizenship. Big things are not good." (Anne)

In the answers, EU citizenship was linked to two issues: patriotism and freedom of movement. Instrumental attitudes were more prevalent in discussions of EU citizenship compared to discussions on national and especially multiple citizenship:

"[EU citizenship] is good for travelling and doing business" (Ants).

Just as in case of decision makers, most of the respondents were hesitant concerning significant expansion of the content of EU citizenship.

"The EU will never develop according to the US model. .... Senseless, it should be made in other way" (Karl).

However, the positions were often relatively moderate, and there were also positive attitudes on a deeper EU citizenship. While the respondents more negative towards EU also expressed more patriotic attitudes on national citizenship, more optimistic attitudes towards EU citizenship were connected to instrumentalist argumentation. 
What is even more important in this connection is, however, a general lack of knowledge about EU citizenship:

"If such a thing [EU citizenship] were invented, it would be positive" (Olesja).

Many interviewees just expressed their general attitudes on EU as a first reaction, and usually the actual content of EU citizenship had to be explained. Knowledge about multiple citizenship was also partial among multicultural people and, as a rule, only the people having multiple citizen acquaintances made at least some reference to cases of multiple citizenship.

\subsection{Practical experiences with multiple citizenship}

It was only possible for multiple citizens to answer this set of questions. As already mentioned, multiple citizenship is illegal in Estonia, and it is evident that multiple citizens do not express their dual status very publicly. It is possible that their family members and close friends would have some practical experiences with multiple citizenship, but we were unable to reach any multicultural persons having very close contacts with multiple citizens and/or ones who would agree to talk about these experiences.

All in all, there were relatively few aspects practically addressed in the context of multiple citizenship. Even in case of multiple citizenship the first reaction usually was to discuss the issues of one's identity and belonging. These were predominantly defined in the context of Estonia by multiple citizens with both western and eastern background:

"I feel only as Estonian - even if I come from Sweden and have lived also in Germany" (Uudo).

"Estonia is my homeland. Canada is the land of birth, both are important" (Juhan)

"I am loyal to both countries [Estonia and Russia]" (Evi).

If directly asked about practical use of their multiple citizenship, the first reaction often was that of there being no practical effects. In subsequent discussion some more aspects were addressed. The main reason for obtaining multiple citizenship was real connections to the titular states: ethnic origin and/or the interviewee's need to move to another country:

"I came to work here in Estonian-Canadian law office. Then I decided to stay here" (Kristjan)

"In both countries where I live and that are important to me, I have the destiny to participate" (Juhan). 
While the general pattern among multiple citizens was similar, the situation of returned Estonian exiles and Soviet time settlers of Estonia differed. Estonian exiles discuss their multiple citizenship in the context of involuntary flight from Soviet army, practical necessities in the host country and gratitude to the former state of domicile.

Soviet-time settlers emphasised their connections to the friends and relatives in former USSR area. This topic was present in the discourse of exiles but not so prevalently. The Soviet-time settlers are unhappy about the barriers to movement and treat their multiple citizenship as a personal strategy for overcoming the barriers imposed by competing post-Soviet politicians.

Most of the motivation for obtaining multiple citizenship was related to guarantees of personal security and, in the case of exiles, employment considerations. Nowadays the majority of returned exiles seldom or never use their other citizenship. However, among younger returned exiles there were cases where both travel and social benefits of the country of their other citizenship were used:

"With my two passports I can travel through all Eurasia" (Tiina).

"The advantages of dual citizenship are free medical aid and pension of Canada and also some more possibilities to travel without visa requirements" (Sander)

The motivation for obtaining multiple citizenship for people with Soviet background is predominantly related to travel possibilities for meeting their friends and relatives. In this context, multiple citizenship is also used in practice. Estonians or people from mixed families living mostly abroad (i.e. they are not permanent residents of Estonia) also use their Estonian citizenship to access free public education here:

"I came to study into university to Estonia as it is free to citizens" (Tiina).

The persons with multiple citizenship generally seem to be a group of very active people (with the exception of retirees). Multiple citizenship seems to be evaluated positively mostly because of the travelling opportunities, but also for business purposes (we found two persons in this category, namely cross-border business dualcitizen entrepreneurs ready to give an interview).

Summing up, multiple citizenship is mostly used for travel, not for residence. In order to bypass the visa and other requirements, appropriate passports are used without many other practical effects. However, in some cases multiple citizenship may open up additional possibilities concerning educational and social benefits, enabling those with multiple citizenship to use the best of both countries. In such cases multiple citizens hold an especially low profile.

\subsection{Substantial dimensions of citizenship and multiple citizenship}

The positions interviewees took on loyalty did not offer much surprise. Both multiple citizens and multicultural persons generally declared loyalty to the country of their permanent residence or current stay, i.e. Estonia: 
"I am normally loyal to Estonia" (Kolja).

However, quite a few interviewees also stressed the importance of friends and other contacts, as well as familiar environment:

When asked how they define loyalty, the general response of the interviewees was that they will stand for Estonia in public discussions. There was also some linking of loyalty to defending one's country:

"Citizenship means I have the right to both praise and criticise my country" (Katrin).

At the same time, identity was also an issue for more consideration. While loyalty had predominantly political connotations, identity was addressed in connection to one's friends and contacts in addition to the context of political belonging and cultural membership:

"My identity is based on Russia but my political loyalty is with Estonia" (Lydia).

Generally, the interviewees ended up speaking of multiple identities, with the Estonian political identity being the most prominent or one of the prominent affiliations.

While the returned exiles defined themselves as Estonians, some of them defined themselves secondarily also as Europeans, as intermediaries between their two countries of citizenship, or even as citizens of the world:

"Both are important. The USA has been an important period in my life - 12 years. Now I live in Estonia" (Rain).

"I also feel like a world citizen" (Liia).

The interviewees of non-ethnic-Estonian origin - in the case of our study, of Russian or other FSU ethnicity - generally defined themselves as culturally Russian (or respective other FSU ethnicity), but as a Russian of Estonia. Politically, they defined themselves as members of the Estonian state:

"I feel I belong to Estonia although I was born in Russia" (Tolik).

"My identity is based on Russia, but my political loyalty is with Estonia" (Lydia).

Usually the non-ethnic-Estonian interviewees clearly recognised the importance of the political and everyday socio-economic and socio-cultural experience of the country of residence:

"My identity is that I belong to Estonia. This is my country of birth. I feel close to the nature, mentality, culture, people, rhythm of life" (Stir). 
They even condemned the portion of Soviet-time residents living in a kind of private escapism or isolation by watching Russian TV at home and minimising practical contacts in everyday social and working life:

"Who doesn't like to live in Estonia, should leave" (Pavel).

Thus we could observe the emergence of an Estonian political identity irrespective of ethnic belonging among the interviewees. This is an encouraging indication of the possibilities of a republican basis of citizenship and citizenship identity. However, it must be noted that the interviews were hardly representative of the multicultural population of Estonia as a whole, and it is most likely we reached only the betterintegrated segment of multicultural persons, while others rejected the interviews or could not be reached.

While we could expect some instrumentalism in practical attitudes concerning the integration into everyday life on the basis of survey among decision makers, we were still surprised at the practically uncontested prominence of the role of individual performance in the responses of interviewees. The views of the two subgroups did not differ in this respect.

The usual first reaction to the question on full membership was to state that everyone is equal before the law and thus everyone is a full member of society. In addition to that, one is seen as being the architect of his or her own fortunes. This holds both for the interest to participate and reflections on actual personal status in society.

The fullness of citizenship or the quality of membership in society was seen as in principle depending on the activeness and success of the person him- or herself and the notion that there is little to be done for other people or public institutions. Such attitudes were compatible with the understanding of citizenship as an essentially political and legal phenomenon connected to nation state, patriotism and loyalty. The social dimension of citizenship seemed to be discursively weak, and the prevalence of individualistic attitudes provided a basis for neo-liberal discourse:

"I participate little, but I know I have the right to participate as much as I wish" (Tanja).

"I am a business woman, too much a rolling stone to much participate in social life" (Liia).

At times it seemed as if the interviewees tried to persuade themselves that everything depends on their effort, that it is their own fault if they experience difficulties and that, if they struggle hard, they will end up being the masters of their own destiny and well-being:

"I would have all the rights - if I just wanted to and was active" (Pavel).

Many interviewees were clearly both rational and calculating when discussing their opportunities. Here even the general patriotic attitudes were somewhat overshadowed. This was most visible in the context of possible emigration. While the older returned 
exiles $^{3}$ remained true to their decision to stay in their native country, the younger exiles and multicultural persons considered the practical option of leaving for employment:

"I obtained dual citizenship in order to work in the Estonian foreign service" (Sch).

Expectedly, the main context for discussion on the participation in society was the national level. Both local and EU levels of context were surprisingly weak, but for different reasons. The local level was usually discussed inseparably from the national. Opportunities on the EU level, if generally welcomed in the context of freedom of movement, were in fact largely unknown and as such did not form an important point of reference. World citizenship was not part of how a substantial of the portion of respondents perceived the questions.

$* * * *$

All in all, the substantial dimensions of citizenship show a pattern compatible with the results of other stages of the interview. General patriotic sentiment was clearly dominant in discussions of loyalty and present in discussions of identity. Identity was also connected to the interviewee's social network.

On the other hand, attitudes on full membership in society reflect the prominence of individualism, pragmatism and instrumentalism concerning everyday life. The issues of civil and social citizenship were not addressed as citizenship and sometimes not even in the context of full membership in society. If directly asked, interviewees usually discussed these issues in terms of public provisions of welfare, not citizenship. Here, neo-liberal attitudes were relatively prominent, but the need for benevolence and some kind of social cohesion was also often expressed.

Despite a generally similar pattern concerning the substantial dimensions of citizenship, there seem to be some differences between the returned exiles and Estonian multicultural residents. The nationalism of the exiles has been influenced by the experiences of mainstream tolerance in the former host society. In contrast, the attitudes of multiple citizens can be explained in the context of self-persuasion, primarily in order to overcome the situation of belonging to a minority attempting success in a restored nation state.

\section{Main discourses}

Having examined the main positions of the interviewees, it is appropriate to proceed to the main lines of argumentation that we identified from the interviews. The basis of the subsequent discussion is the types of discursive logics developed by the interviewees. We will first bring out the discourses in general and then focus more

\footnotetext{
${ }^{3}$ It is worth mentioning that many of the older exiles have retired. As a rule they are better off in Estonia than in the country of former employment. This is because their pension goes further in Estonia due to lower living expenses. However, this should not to be thought to lessen their patriotic sentiment, as expressed in the interviews.
} 
specifically on the sets of attitudes prevailing among multiple citizens and multicultural persons separately.

Generalising the interviews, we can identify four main lines of argumentation with regard to national, multiple and EU citizenship:

1. Mainstream pragmatism. National citizenship is the main context of reference in accordance with the above examination. The position is characterised by general patriotism and some flexibility regarding practical arrangements. Thus multiple citizenship is not supported, but the current silent tolerance of multiple citizens is not criticized much either. The European Union and EU citizenship are accepted and even liked in their present form (as an additional bonus to Member State citizenship). But in case of EU citizenship being redefined so that Estonian identity and sovereignty would seem to come under the threat of marginalisation, the attitudes of interviewees were clearly negative (even if not aggressively so). In some ways the attitudes are relatively conservative, with a classical concept of citizenship lying in the background. Such lines of reasoning characterised the responses of the majority of respondents of various generations both ethnic Estonians and Russians, from East and West.

2. Estonian nationalism. The main topics of interest (and concern) are the development of the Estonian culture and the sovereign nation state. A conservative approach to citizenship is complemented by a strong cognisance of national political and cultural community. National citizenship is understood as an exclusive relation based on emotional affiliation and committed membership. Multiple citizenship is rated negatively, even if it is sometimes accepted as tolerable in certain practical circumstances. EU citizenship is regarded with suspicion, although there also are some direct signs of opposition to. Wishing to keep the EU experiment within „reasonable" limits, there should be even fewer supranational structures in some areas (although some respondents are supportive of common an EU foreign and defence policy). Some respondents in this category were ethnic Estonians, most of whom are exiles returned from the West.

3. Eastern orientation. Connections to the cultural space of Russia and all the former Soviet Union. Contacts with FSU countries are regarded as the most important. The idea of national citizenship and its exclusiveness is well understood and logically accepted. However, travel interests and interests in contacts clearly lean towards flexibility, resulting in mixed attitudes on multiple citizenship. The European Union and EU citizenship are associated with the general pattern of westernisation in contemporary Estonia, thus the general attitude toward westernisation - though not aggressively opposed, is one of reluctance. We can speak of a mostly culturally-based hesitation. Sometimes the viewpoints have been more deeply considered, hence the opposition more concrete. Among our interviewees there were only some people clearly falling into this line of reasoning. Such weakness is somewhat surprising but may be explained by the composition of the body of interviewees. 
4. Welfare instrumentalism. The key issue of interest is maximising personal welfare. Everything is good if it enhances personal well-being and material welfare. National and multiple citizenship are not of special relevance other than as the basis for employment and other socio-economic action. As long as European Union is understood to be improving welfare, the strengthening of the supra-national features of the EU and EU citizenship are welcomed. A position that Estonia is too small for economic efficiency clearly has prominence in this context, being the main reason for supporting the strengthening of European Union. There are rather many supporters of these positions among both ethnically Estonian and Russian youth.

The discourses can be better understood and interpreted with reference to other research concerning societal integration, which has been conducted mainly with regard to Soviet-time immigrants in an emotionally ambiguous position after the collapse of the USSR. However, such people do not comprise a homogenous group. "Soviet people" belonging to older generation perceive themselves as not being obliged to apply for citizenship in the "new" state (i.e. Estonia). Instead, they express their natural affiliation to place, which is in terms of mental identification with their country or votchina (historical territory) as they have learned from Soviet-time narratives and have experienced for decades. This explains why an absolute majority of immigrants long (i.e. at least up to the middle of the nineties) perceived the "zero option" and dual citizenship (Estonian/Russian) as "fair" and as a "norm" (Estonia's Experiment 1997; Estonia's Non-citizens 1997).

Estonian EU membership and effective integration Estonia into the market economy made the position of non-Estonians more and more ambiguous and also created a visible gap between generations, particularly in the values of the old, middle-aged and younger generations. The middle-aged and younger generations show more respect toward the present Estonia. Some other studies reveal important changes in structure of values in the younger generation of immigrants. National security, the environment and independence occupy the last places in the concerns/values of younger and middle-age non-Estonian residents. In families founded by a younger cohort of nonEstonians, rationality, utilitarianism, the capability for adaptation, success, personal autonomy and so on have taken central place as dominant values (Järva 2003). According to this study an absolute majority of parents maintain national heritage and only one quarter feel that they fully belong to Estonia. At the same time they are highly interested in ensuring that their children are competent in the Estonian language and culture. About two thirds perceived Estonia as their homeland and a quarter both Russia and Estonia. Only every tenth declared that they instruct children first of all to be citizens of Russia, and almost one half believed their children to have become patriots of Estonia. About one third saw descendants as citizens of EU or of the world and future residents of some EU country or the USA. Only one tenth of parents perceived the future of their children as connected to Russia (Järva 2004). These and other findings are very informative for interpreting of our interviews.

Younger generations (both Estonians and non-Estonians) already do not share in the traumas of the past to the full. Younger generations of immigrants and their children who have grown up in the Estonian Republic don't face such a pressing need to redefine a "Soviet" identity. Citizenship requirements are just practical issues, and the Estonian language is perceived as a symbolic value important for integration with 
Estonian society (Vihalemm 2002). New competencies serve for naturalization/accommodation among the ruins of collapsed utopia. In political terms "citizenship requirements" serve as "marks of loyalty" and are connected first of all with the future. The younger generations of Estonians also do not perceive themselves as "agents of history" or as members of the "community of fate" (Kirch 2002,100). However, "securitizing discourse" rationalizing the citizenship policy of Estonia, even if not entirely fair to them, may be seen as a justified "defensive" strategy.

\subsection{Profiles of multiple citizens}

We can distinguish three main lines of argumentation reflected in the interviews with multiple citizens:

1. Nationally minded discourse. Usually among the older returned exiles, also among some middle-aged and younger people. They understand citizenship principally in classical terms, based on mutual deep attachments and loyalties. The basis for identity is Estonia as a homeland. Their loyalty towards Estonia is unquestioned but sometimes complemented by attachment to the country of exile as well. It concerns not only social networks, but this group has deep feelings of gratitude towards their former host countries.

This observation firstly concerns persons belonging to the older generation. They also feel slightly ashamed of their multiple citizenships because they understand this as a partial disloyalty towards Estonia. At the same time they either are afraid of possible Russian aggression in the future and want to retain the opportunity to leave, feel partly attached (or at least thankful) to the country of exile, or just haven't bothered to renounce their other citizenship.

They usually consider themselves full-scale citizens in all of the Marshallian dimensions. They expressed some confusion and complaints on being regarded not as "pure" Estonians and on incomplete democratisation in the field of politics. But, in general, they are satisfied with their status. People from the older generation express doubts on active participation in Estonian politics. They don't feel at home in the domestic affairs of Estonia, but the majority of them declared sympathies towards nationalist parties.

Multiple citizen interviewees of the older generation perceive EU citizenship as something instrumentally important, but they very strongly deny EU citizenship as a "real" citizenship or an alternative to Estonian citizenship.

2. Pragmatic cosmopolitan discourse. These attitudes characterise some people of both western (US and EU) and eastern (FSU) origins, but the latter may be prevailing (we even discovered some people from the FSU now holding multiple citizenships in the form of a citizenship in Estonia and simultaneously in some other EU state). This category predominantly hosts socially active, middle-aged or younger people, many of mixed families. They regard citizenship instrumentally, without significant considerations of loyalty. The main question is: what can citizenship be used for? The identities and loyalties within this group are mostly connected with personal contacts, 
especially friends. Dual citizenship is a tool for personal purposes, especially travelling but in many cases also for looking for jobs.

Among them is quite a big share of foreign-born younger Estonians, who, because of their excellent language competence, modern education, work experience, etc., were hired in Estonian state administration. The postcommunist gap in development and civilisation between the West and postcolonial Estonia (but nowadays also Russia) opened up new career perspectives.

This interviewees of this subgroup are not dominated by particular citizenships, and they consider the entire world their home. They usually consider themselves full-scale citizens in all the Marshallian dimensions. Within this group there is much concern about national-level issues and a very positive attitude towards EU and EU citizenship.

3. Cautious privatistic discourse. These attitudes characterise some Estonian emigrants (who left after Estonia restored its independence for jobs in the West and who later returned) and some Estonian inhabitants of FSU origin. The respondents in this category are usually less educated. Citizenships and passports do not imply any special feelings and are used as tools for crossing borders, collecting social welfare, etc. People try to appear mainstream and unnoticeable and do not express strong national loyalties. The FSU respondents compare their current standard of living to the one of their contacts of the FSU countries and think that they are better off, but they have not adapted into Estonian society well. One could notice some feelings of alienation. Many such people did not agree to participate in interviews. These people cannot indicate their full usage of Marshallian dimensions but are nevertheless stating they have no problems - everything depends on the person as an individual.

\subsection{Profiles of multicultural persons}

In cases of multicultural interviewees, we based our discussion on societal integration in the context of becoming full-scale citizens in Marshallian dimensions. On this basis, we can distinguish four main discourses reflecting different stages of integration. As respondents in the multicultural group are generally younger, as well as more active and open, these attitudes reflect various perspectives of integration within the group but not reflect a reluctance to integrate:

1. Path seeking. Strong emotional connections to the FSU home country, predominantly with Russia. Parents late Soviet-time immigrants, or Russocentrics, or living in former military areas and/or some Ida-Virumaa cities that have mainly Russians as inhabitants. Clear self-identification as Russia/Belarus/Ukraine but also as a non-Estonian in Estonia. There is also a clear cultural distance with the relatives in Russia as experienced through practical experiences. The person has decided to remain into Estonia and understands that in order to be successful one must be active in society. Thus he/she learns Estonian and looks for positions in Estonia. Usually he/she has already gotten Estonian citizenship, normally via naturalisation. An important 
step towards integration is university-level education in an Estonian university rather than in a Russian one with a department operating illegally in Estonia.

There is some frustration (especially among male respondents) due to the feeling of being disadvantaged from the start (i.e. disfavoured as non-ethnic Estonians). A large share of this group had strong national feelings they actually dared to express. They perceive themselves, despite their efforts to integrate into Estonian society, as somewhat alienated and distanced from the community of the Estonians. Such attitudes seem characteristic of a relatively large group of the Russian-speaking minority that must somehow find its social place in the future.

2. Integrating. Participating actively in social life in instrumental terms. Parents have some vague or, in some cases, more developed connections to everyday life in Estonia. This group was educated in schools of Russian-language instruction but adapted to both Estonian and transnational popular culture at the consumerist level. They speak relatively fluent Estonian and have ethnic Estonian friends, acquaintances or partners.

People of this group often regard both staying in Estonia and leaving Estonia as practical options: Leaving Estonia means life in the West and employment opportunities. Their national sentiments are weak and their identities vague. Estonia may look to be too tiny for people who are experienced to think in broader categories. Estonia is a nice place, but it is not necessarily their destiny. General attitudes are quite pragmatic and based on personal welfare. All respondents have been very interested in Estonian citizenship in instrumental terms and have obtained this some time ago either through naturalisation or already through parents (i.e. currently they are citizens).

3. Fully integrated into Estonian society. People in this group originate from well-adapted families that came with the first immigration wave to Estonia during the forties or fifties and often are from mixed Estonian/Russian, Russian/Ukrainian, etc. families. Sometimes they originate from some smaller Estonian towns in the southern or western parts of the country, where the bulk of the population are ethnic Estonians. They perceive themselves as being much different from the "late migrants" (who arrived in context of next migration wave in seventies) and as a group close to their Estonian countrymen.

They have decided to stay to Estonia and hope to be successful in their life career. They often are hesitant in defining their ethnicity but regard themselves mostly as ethnic Estonians. (A lot of problems take root from language deficit - there is no word in the Estonian language for indicating Estonian citizens of non-Estonian ethnic origin). Culturally, they are fully integrated and externally indistinguishable from other Estonians, although there may be some minor internal confusions. In principle they are not different from other ("mainstream") ethnic Estonian youth. At the same time they well understand and evaluate their other culture and even use this for some purposes - even though they might have been the last generation from this wave of immigrants. They comprise a great resource of the Estonian society, both in the context of 
continuing integration and in developing effective contacts with many countries.

4. Ethnic Estonians with a multicultural background. These mostly are exchange pupils for one to three years, or they are children who are sent to study in Estonia by parents who left Estonia because of job opportunities, which allows them to make a subsequent choice of which state to declare as their country of residence. They often have rather noticeable national/patriotic sentiments, which are also reflected in attitudes toward the post-colonial diaspora as such (not on a interpersonal level) and are not necessarily pragmatic. At the same time they usually have warm feelings towards their other country of residence/experience. Having grown up in a welfare society, they seem to be a bit less "grown up" when compared to the local people with tougher challenges in life. Often they don't have clear-cut attitudes concerning the issues of citizenship or actual participation in society.

\section{Conclusions and recommendations}

Summarising the above discussion, we could broadly state that the key positions in the survey among decision makers were also broadly reflected in the attitudes of multiple citizens and multicultural persons. Thus, their stories are not so marginal, after all.

There is some kind of common architecture in the narratives of the elites and people in the contact zone. Modern nationhood as general context of reference, complemented by pragmatic instrumentalism and relatively little information on citizenship issues, thus seem to be a relatively widespread pattern in Estonia.

The contradictions of general nationalism and pragmatic instrumentalism could possibly be used as a resource for changes towards more open solutions in national citizenship policies. However, people actually affected generally understand the current settings as reasonable.

The attitudes of multiple citizens and multicultural citizens as such did not differ significantly; the orientations were more influenced by socio-cultural background (West vs. East). However, multiple citizens seem to represent a more active part of population in practice, irrespective of origin.

Multiple citizenship is not a popular concept in such attitudinal contexts, even among the groups of interviewees most likely to be in favour of it. Multiple citizens themselves are sometimes embarrassed about their multiple citizenship. Holding many passports simultaneously is mostly connected to travelling. European Union citizenship is accepted in its current form, but there seems to be little rationale seen in significantly expanding its scope.

There were almost no respondents who regard themselves as less-than-full participants in societal life within any of the Marshallian dimensions, neither before nor after explaining the nature of civil, political and social citizenship and asking 
further similar questions. At the same time the respondents were aware of their modest actual participation in many fields.

The background logic behind this situation is that everything is perceived by interviewees as depending on personal effort. If one is interested and active, one can participate fully in whatever field one wants and may achieve almost whatever one wants to achieve. It is merely that the respondents do not want to participate. These attitudes may partly indicate a liberal type of articulation of self and societal consciousness. This is most probably related also to the underdevelopment of the concept of social citizenship in public discourse.

There seems to be widespread instrumentalism and welfare orientation among younger interviewees. This may be partly explained by the fact that many of the Soviet-time immigrants had predominantly economic (welfare) motivations, which possibly reflect also in the attitudes of younger generations. However, younger ethnic Estonians also partly share these attitudes. As such, one possible explanation could be the general instrumentalisation of values and attitudes referring to a more homo oeconomicus type of behaviour. Hegemony of such a kind of mindset is most likely related to the confused state organisation characteristic of most of the central and eastern European countries.

Both of these types of self and world conceptualisations are especially telling for policy makers. Multiple citizens and multicultural persons, most likely almost all ethnic Estonians, need some shared spaces to develop strategies enhancing their interest in engaging in public affairs. The nature of such strategies is a separate discussion topic.

Since the collapse of Soviet Union, minorities living within Estonia have had to reconstruct their identities. Estonia has been transforming into to a more multicultural society than Soviet Estonia was. Instead of communitarian membership with the "Soviet people", the institution of citizenship is a constitutive element of present-day Estonia. Dilemmas related to citizenship pave the way for understanding the Estonian nation-building process. Adaptation into Estonian society is seen both as inevitable for active participation and as a natural choice for anyone who wishes make career in Estonia. The better-adapted ethnic Russians were mindful that people who do not like Estonia should prefer to emigrate.

Security comprises one of the discourses that has an important role to play in postcolonial Estonia. It is obvious that there is a considerable variation in the ways in which the security discourse is linked with the identity/loyalty discourse, and also in the ways in which it has been articulated in terms of citizenship. In case of the Russophones' post-modern identity politics, the linkage remains relatively loose. Collective/group but also personal security is not a topical issue for "Russophones" as much the latter is essential to Estonians. It is important to underline that despite significant frustration over the issue of security, signifiers such as security, success, achievement, freedom, etc. represent Estonian citizenship (which now is EU citizenship). For "Russophone" respondents, they are relevant labels for hope in an optimistic future, effective personal "agendas", or "life projects". Shifts in citizenship status (i.e. gaining Estonian citizenship) is first of all marked by the sense of relief and optimism. 
Discourses on Estonia among immigrants usually do not contain any important structural elements, which were essential for building of the exclusive nationalist discourse. These discourses contained the following elements, which also are important for understanding attitudes of the Estonians in respect of dual citizenship:

- a set of (historical) ideas related to the glorification of the pre-war Estonian Republic;

- narratives/assumptions on the existence of legal continuity between the past and modern Estonian states;

- the display of Estonians as the only agents of independence movement (which marginalised Russians as immigrants); and

- citizenship as an element of fundamental value to the sustainability of the nation.

Effective citizenship policy expects that alongside substantial forms of identity there is also room for some other forms of membership. Non-fundamentalist memberships operate as patterns of citizenship first of all for the "Russophone" minority (as our study revealed, these can be shared also by some groups of the ethnic Estonians). According to some studies, the formation of civic identity has made significant progress during the last decade (firstly among younger generation). Civic identity is connected with political identity, and they support each other, but civic identity is feasible even when political identity is quite weak.

In a broad sense civic identity is the feeling of attachment to state and society; a cognition of commonality of interests with all members of society (Vihalemm 2001; Jakobson 2002). Civic identity has taken root when:

1) the norms and laws of the society are taken as a basis for discussion, the position of the dominant ethno-class is accepted and there is consensus that any change in its position could be achieved only according to the rules and laws of host society;

2) there are some cultural elements (communicative tools, cultural norms, symbols, etc.) common to different segments of society;

3) the different ethno-cultural and social parts of the society recognize that they have common interests and see themselves as parts of the same wider system (Smith and Wilson 1997).

Even if signs of frustration and alienation have made inroads in the Russophone society, these elements of civic identity pattern integration (nation building) constitute the main resource of citizenship as an instrument of civic integration in Estonia.

Along with the other perspectives, it appears that research on citizenship issues opened up one of the most promising/illuminating approaches for understanding/articulating new challenges related to the nation building and EU integration in the post-colonial Estonia; a country which today is in a globalising world. Both national, multiple and even EU citizenship are kinds of responses to the challenges of transforming realities in Estonia and in Europe. We discovered that a set of different types of identity constructions, loyalty constructions and practical strategies for paths in life have developed and can exist side by side. 
An important difference can be observed in terms of attitudes towards dual citizenship and EU citizenship between groups of returned exiles and their descendants, which quite largely is coincident with the gap between older and younger generations.

The older generations of the exiles with dual citizenship (40 years and older) share mainly a strong nationalist/exclusionist perspective on a dual citizenship. This understanding treats dual citizenship first of all from the perspective of the sustainability of the Estonian nation and bears a strong emphasis on immigrant assimilation (or integration). They represent attitudes that are popular in Estonia in general and close to methodological nationalism or "sedentarism". Sedantarism represents a notion that immobility and national/local rootedness constitutes the normal and described condition, whereas migration is a deviation from normality (cf. Faist 2000). For many of the people who comprise this group, such emphasis has its background in not only nationalist mindsets (education at home), but also in the alarming experience from their host countries (Canada, Sweden England etc). Largescale immigration and misuse of multiple citizenship have made many of former exiles, who returned from these countries, concerned about the future of Estonia.

The position of the younger generation of exiles (aged 40 or less) is closer to the transnational understanding of dual citizenship. Their perspective is also quite taken with the nationalist view but is not as developed as the "methodological nationalism" of the older generation. They link multiple citizenship to the EU and perceive/interpret dual citizenship as an instrument to make use of transnational resources. This position has its background in their own experience of living and studying in different countries. Yet this very "international" group/generation cannot abandon security issues from their discourse, as Russia remains in the picture.

The younger generation of "Russophones" which formed the main group of respondents (i.e. Soviet immigrants with multicultural background) tend to entertain multiple identities and loyalties simultaneously. "Estonianess" is defined first of all in terms of loyalty. "Russophones" seem to display a post-modern identity politics with multiple loyalties but lacking a clear pattern that fits with the findings of other scholars (cf. Vetik 1999, 11).

Unfortunately, we had not planned to ask about the attitudes of people holding one citizenship (i.e. "Russphones") in terms of how they rank the option of dual citizenship. (According to other studies it is preferred by a big share of non-Estonians form of citizenship.) However, a large number of narratives revealed that single citizenship is as relevant as dual citizenship to the identity structure of non-Estonians. Our study seems to support the idea that, for the ethnic Estonians, primordial and hierarchic modes of identity politics are the most commonplace, and, among the Russophones, post-modern identity construction prevails (cf. Aalto 2001, 22).

Two processes run simultaneously - the integration of post-colonial space and the effective integration of Estonia into the globalising world are in clear conflict in modern Estonia. Coming to terms with them demands policies that cannot be productive in all perspectives. Some shift towards a more flexible and liberal approach in respect of dual citizenship appears to preferred. 
In making Estonian society more transparent and capable of coming to terms with challenges produced by globalisation and developing of transnational communities, the following are expected of Estonian decision makers:

- along with the identity policy typical to "nationalising state" exercised thus far, loyalty (civic citizenship) should be perceived as an exhaustive constitutive element for the development of effective societal bindings;

- multicultural models of "Estonianess" should be developed as an element of contemporary nation building; and

- immigration policies should be developed to ease serious future problems likely to arise due to depopulation. Multiple citizenship is one the instruments of such complex policies. 


\section{Bibliography}

Aalto, Pami (2001). Constructing Post-Soviet Geopolitics in Estonia. A Study in Security, Identity and Subjectivity. University of Helsinki.

Andersen, Jorgen Goul and Hoff, Jens (2001). Democracy and Citizenship in Scandinavia. Houndmills and New York: PalgraveMcMillan.

Rainer, Bauböck and Rundell, John (eds.) (1998). Blurred Boundaries: Migration, Ethnicity, Citizenship. Aldershot, Brookfield, Singapore, Sydney: Ashgate;

Castles, Stephen and Miller, Mark J. (1998). The age of migration: International Population Movements in the Modern World. $2^{\text {nd }}$ Edition. New York: The Guilford Press (quoted via Fishman et al 2006).

Castles, Stephen and Davidson, Alastair (2000) Citizenship and Migration.

Globalization and the Politics of Belonging. Houndmills and New York: Palgrave.

Eesti Vabariigi põhiseadus/Constitution of the Republic of Estonia (RT 1992, 26, 349, RT I 2003, 29, 174; 64, 429).

Estonia's Experiment (1997). Estonia's Experiment - The Possibilities to Integrate Non-citizens into the Estonian Society. Conducted by Tartu University Market Research Team.Tallinn.

Estonia's Non-citizens (1997). Estonia's Non-citizens: A Survey of Attitudes to Migration and Integration. IOM International Organization for Migration.

Faist, Thomas (2000). The Volume and Dynamics of International Migration. New York: Oxford University Press.

Hammar, Tomas (1990). Democracy and Nation State. Aldershot, Brookfield, USA, Singapore, Sidney: Ashgate.

Data of the Statistical Office of Estonia. http://www.stat.ee (04.10.2005).

Heater, Derek, (1999). What is Citizenship? Cambridge, Oxford: Polity

Press/Blackwell Publishers.

Jakobson, Valeria (2002). Role of the Estonian Russian-language Media in the Integration of the Russian-speaking Minority into Estonian Society, Acta Universitatis Tamperensis, Vol. 858.

Järva, Inna (2004). Põlvkondlikud muutused Eestimaa vene perekondade kasvatuses. http://www.sotsioloogia.ee/esso3/5/inna_jarva.htm (07.09.2005). 
Kalev, Leif and Rein, Ruutsoo (2005). "Citizenship and Multiple Citizenship in Estonia”. In: Yvonne M. Schröter, Christoph Mengelkamp and Reinhold S. Jäger (Hrsg.) Doppelte Staatsbürgerschaft. Landau: Verlag Empirische Pädagogik.

Kalev, Leif and Ruutsoo, Rein (2006) "The Shadow of the Past and the Promise of the EU: National and Multiple Citizenship - The Estonian Case". In Devorah KalekinFishman and Pirkko Pitkänen (eds.) Dual Citizenship as a Challenge to European Nation-States. London, Thousand Oaks, New Delhi: Sage Publications (In press), pp. 180-201.

Kalev, Leif and Ruutsoo, Rein (forthcoming). Balancing Nation State Building and Globalisation: Attitudes of the Decision Makers of Estonia. Manuscript to be published in DCE project by University of Tampere Press.

Kirch, Marika (2002). "Eesti ja Euroopa identiteet”. Rmt. Aune Valk (koostaja). Eesti ja eestlased võrdlevas perspektiivis. Tartu: Tartu Ülikooli Kirjastus, pp. 87-102;

Kodakondsuse seadus/Citizenship Act (RT I 1995, 12, 122; 83, 1442; 1998, 111, 1827; 2000, 51, 323; 2001, 93, 565; 2002, 53, 336; 62, 376; 90, 518; 2003, 18, 101 ; $82,550 ; 2004,12,80 ; 84,570 ; 2005,61,472)$;

Marshall, Thomas H. (1992) [1950], "Citizenship and Social Class". In Thomas H. Marshall and Tom Bottomore Citizenship and Social Class. London: Pluto Press, pp. 3-51.

Pettai Iris ja Proos, Ivi (1999). Millal mitte-eestlasest saab Eesti kodanik? Kommenteeritud andmebaas. Tallinn: Eesti Avatud Ühiskonna Instituut.

Ruutsoo, Rein (2002). "Discoursive Conflict and Estonian Post-Communist Nation Building". In Mati Heidmets and Marju Lauristin (eds) The Challenge of the Russian Minority. Emerging multicultural Democracy in Estonia. Tartu: Tartu University Press, pp. 31-54.

Smith, Graham and Wilson, Andrew (1997). "Rethinking Russia's Post-Soviet Diaspora: The Potential for Political Mobilisation in Eastern Ukraine and North-east Estonia”. Europe-Asia Studies. Vol. 49, No. 5, pp. 845-864.

Vihalemm, Triin (2002). "Eesti keele roll kultuuridevahelises kommunikatsioonis". Rmt. Aune Valk (koostaja). Eesti ja eestlased võrdlevas perspektiivis. Tartu: Tartu Ülikooli Kirjastus, pp. 246-260.

Waters, Malcolm (2001). Globalization. $2^{\text {nd }}$ Edition. London and New York: Routledge. 